\title{
DYLEMATY BADAŃ ZJAWISKA I POJĘCIA RYZYKA ${ }^{1}$
}

\author{
Tadeusz Teofil Kaczmarek \\ Uczelnia Łazarskiego w Warszawie \\ Wydział Ekonomii i Zarządzania \\ adres, e-mail: tadeusz@kaczmarek.waw.pl; www.kaczmarek.waw.pl
}

\begin{abstract}
Streszczenie: W opracowaniu tym został dokonany chronologiczny przegląd badań prowadzonych nad ryzykiem, a następnie analiza relacji występujących między teorią nauki w odniesieniu do ryzyka oraz wykorzystania metodologii naukowej w tej nowej dyscyplinie. W szczególności przedstawione zostało zagadnienie doskonalenia narzędzi pomiaru ryzyka. Prowadzone są również wstępne rozważania nad interdyscyplinarnym badaniem zdywersyfikowanego ryzyka. Przedstawione zostały w nim strategie zmierzające do ograniczenia globalnego ryzyka i powstających zagrożeń dla środowiska naturalnego wykorzystując tu raport Human Choice and Climate Change. Nie można też było pominąć kwestii eksplozji informacji i jej wpływu na dalsze badania ryzyka, a także znaczenia modnych obecnie badań transdyscyplinarnych. Esej kończy próba odpowiedzi na pytanie dotyczące odpowiedzialności uczonych za skutki prowadzonych badań. Stanowi także wprowadzenie do badań nad filozofią ryzyka.
\end{abstract}

Słowa kluczowe: Zarządzanie ryzykiem, ujęcie interdyscyplinarne, metodologia badań naukowych, poszukiwanie pewności, narzędzia pomiaru ryzyka, teoria gier, globalne ryzyko, zmiany klimatyczne, eksplozja zasobów informacji, znaczenie badan transdyscyplinarnych.

\section{WPROWADZENIE. - Z HISTORII RYZYKA}

Refleksja, która nasuwa się badaczowi problematyki ryzyka jest złudna euforia, z jaką wkroczono w miniony XX wiek z nadzieją na niezwykłą pomyślność, pokój światowy i szybki rozwój gospodarczy. Pierwsza i druga wojna światowa obaliły mit o doskonałym społeczeństwie i szlachetnym ludzkim gatunku. Co więcej, powstała w nas wątpliwość co do tego, czy świat może się w ogóle bezpiecznie rozwijać. Równocześnie zaczęto sobie uświadamiać różne obszary ryzyka. Zaczęto też two-

1 Artykuł jest skróconą i zmodyfikowaną wersją fragmentu książki autora pt. Ryzyko i zarzadzanie ryzykiem. Ujęcie interdyscyplinarne, (wydanie drugie), która została wydana przez Wydawnictwo Difin w 2006 r., s 13-47. 
rzyć nową dyscyplinę nazwaną zarządzaniem ryzykiem (risk management), która w sposób logiczny, uporządkowany i w miarę spójny zajęła się zdywersyfikowanym ryzykiem. Między innymi zarządzanie ryzykiem rozszerzono na rynki kapitałowe, na których starano się zarządzać aktywami racjonalnie i w ten sposób unikać strat lub je minimalizować. Była to próba wyjścia poza zdarzenia przypadkowe i losowe.

Historia risk management obejmuje ważne zdarzenia ekonomiczne, polityczne, wojskowe, naukowe i technologiczne w minionym XX wieku. Przede wszystkim były to wojny, wynalazki techniczne, intensywny rozwój komunikacji. Inne przełomowe zdarzenia, to wielki kryzys lat trzydziestych, powstanie i upadek systemów totalitarnych (faszyzmu i komunizmu), wynalezienie i wyprodukowanie bomby atomowej, budowa elektrowni atomowych, zagrożenie ekologiczne oraz zjawisko globalnego ocieplenia. oraz szereg pojedynczych incydentów o charakterze negatywnym mających miejsce w różnych częściach świata. Wszystkie te zdarzenia wpływały na rozwój metod i teorii służących rozwojowi nowej dyscypliny z pogranicza zarządzania i nauk ekonomicznych, mianowicie zarządzania zdywersyfikowanym ryzykiem. W genezie jej rozwoju można wyróżnić kilka etapów kształtujących kierunek badań nad zjawiskiem ryzyka. Należy odnotować, że dyscyplina ta najintensywniej była rozwijana od samego początku w Stanach Zjednoczonych.

Pierwsza połowa XX w. - rozwój ubezpieczeń społecznych w postaci świadczeń emerytalnych oraz utworzenie Tanker Insurance Company Ltd., jednego z pierwszych towarzystw ubezpieczeniowych o zasięgu globalnym. Był to sygnał dla przeniesienia ryzyka i odpowiedzialności indywidualnej na przedsiębiorców i rządy. Równocześnie wzajemne ubezpieczenia stały się dobrą i bezpieczną formą finansowania ryzyka. W tym samym czasie opracowano i wydano wyniki badań naukowe nad ryzykiem. $Z$ pośród nich duże znaczenie uzyskały: dzieło Franka Knighta Risk, Uncertainty and Profit., J.M. Keynesa A Treatise on Probability oraz The Theory of Games and Economic Behavior autorstwa Johna von Neumanna i Oskara Morgensterna. Zasługą Knighta jest m.in. to, że oddzielił niemierzalną niepewność od mierzalnego ryzyka. Ostrzegł też przed możliwymi błędami płynącymi z prostej ekstrapolacji przyszłych zdarzeń w oparciu o zdarzenia z przeszłości. W obszarze ryzyka dominują bowiem zdarzenia trudno przewidywalne. Keynes zwracając uwagę na zależność zdarzeń gospodarczych od prawa wielkich liczb przyczynił się do powszechniejszego stosowania rachunku prawdopodobieństwa w naukach ekonomicznych. Natomiast Morgenstern i von Neumann udowadniali użyteczność racjonalnego decydowania i uznali, że ważniejszym celem od chęci zwycięstwa jest dążenie do nie poniesienia strat.

$\mathrm{W}$ latach $50 \mathrm{XX}$ w. rozwijano metody mierzenia ryzyka finansowego oraz zarządzania ryzykiem, w tym ubezpieczeniowe, które do dzisiaj mają swoje zastosowanie. Wśród twórców, którzy przyczynili się do tego należy wymienić Harry Markovitza, Russella Gallaghera, Douglasa Barlowa², Kennetha Arrowa

2 Szerzej: T. T. Kaczmarek, Zarzadzanie zdywersyfikowanym ryzykiem $w$ świetle badań interdyscyplinarnych, Wydawca: Wyższa Szkoła Zarządzania i Marketingu w Warszawie, 2003 rok, s. 90-102. 
i Sir Johna Hicksa. Dwaj ostatni w 1972 r. otrzymali nagrodę Nobla w zakresie nauk ekonomicznych udowadniając między innymi, że ryzyko można ubezpieczyć, przyjmując niezawodne funkcjonowanie prawa wielkich liczb. W kolejnych dekadach powoływano różnego rodzaju jednostki zajmujące się kwestią ryzyka przede wszystkim na płaszczyźnie ekonomicznej. Były to: Risk and Insurance Management Society (RIMS) oraz jego siostrzane stowarzyszenie pod nazwą International Federation of Risk and Insurance Management Association (IFRIMA), amerykańskie towarzystwo: The Society of Risk Analysis (SRA) wydające periodyk, a następnie jego europejski oddział E-SRA, Institute for Risk Management w Londynie i nieco później stowarzyszenie GARP: The Global Association of Risk Professional.

W 1990 r. Sekretariat ONZ autoryzował start INDOR, czyli The International Decade for Natural Disaster Reduction. Był to dziesięcioletni program badania przyczyn i skutków katastrof naturalnych, w szczególności w krajach rozwijających się, a także sposobów zapobiegania tym katastrofom. Program ten został podsumowany w raporcie pt. Natural Disaster Management, w której syntetycznie przedstawiono przyczyny ryzyka, postępujące szybko zmiany procesów społecznych, kwestię przewidywania zagrożeń i zmian, wreszcie sposoby zapobiegania im. ${ }^{3}$ Dwa lata później brytyjski Cadbury Committee opublikował wspomniany wyżej raport w Wielkiej Brytanii, wskazując, że rządy są odpowiedzialne za prowadzenie polityki zarządzania ryzykiem. Podobne działania zostały podjęte w Kanadzie, Stanach Zjednoczonych, w Niemczech i we Francji, dając podstawę do zorganizowania procesu zarządzania ryzykiem na poziomie międzynarodowym. Wykorzystując doświadczenia brytyjskie i kanadyjskie opublikowano w Australii i Nowej Zelandii pierwszą wersję Risk Management Standard - AS/ NZS 4360: 1995 - (skorygowaną w 1999 r.), uwzględniając interdyscyplinarne podejście do ryzyka.

Istotne z punktu widzenia teoretycznego podejścia do kwestii ryzyka było wydanie książki P. L. Bernsteina: Against the Gods: The Remarkable Story of Risk ${ }^{4}$ w 1996 r., która można nazwać kamieniem milowym na drodze do budowania nowej dyscypliny, jaka jest zarządzanie ryzykiem. Bernstein językiem jasnym $i$ zrozumiatym, dokonat syntezy tej złożonej i trudnej dyscypliny, przedstawit jej wybitnych prekursorów w przeszlości, pokazując korzyści, jakie moga osiagnać jednostki oraz przedsiębiorstwa, zarzadzając swoim ryzykiem. W kolejnych latach ta dziedzina badawcza zaczęla wychodzić poza ramy ekonomii i matematyki i znalazła swoich zwolenników w naukach społecznych, rozwijajacych jej metodologię $i$ zastosowanie.

3 International Decade for Natural Disaster Reduction, Report of the UN Secretary-General, General Assembly A/45/621, 16 Oct. 1990.

4 W Polsce książka ukazała się pod tytułem: Przeciw bogom. Niezwykłe dzieje ryzyka. Wydawca WIGPRESS Warszawa 1997. 


\section{GENEZA BADAŃ NAD RYZYKIEM}

Potrzeba prowadzenia naukowych badań nad ryzykiem narodziła się w czasach nowożytnych, ale profesjonalnym pomiarem i kontrolą ryzyka zaczęto się zajmować dopiero w połowie XX wieku.

Faktem bezspornym jest, że ryzyko towarzyszyło człowiekowi od zarania dziejów. Początkowo ograniczone możliwości podróżowania najpierw statkami, a potem koleją sprawiały, że ryzyko nie było jednak zbyt duże. Wiek XVI i XVII, to czas odkryć geograficznych, odkrywania i poznawania nowych lądów i nowych narodów. Zaczęto wówczas intensywnie rozwijać handel z odległymi krajami, czyli eksport i import, które są zwykle obciążone znacznym ryzykiem. ${ }^{5}$ Ale ryzyko równocześnie pozwala osiągać znaczne korzyści. $Z$ nastaniem epoki kapitalizmu, zaczął się rozwój prognozowania, które wiąże podejmowanie ryzyka z osiąganiem zysków. Prognozowanie przyszłych zdarzeń było ważne przy podejmowaniu decyzji o składowaniu i wysyłaniu towarów do krajów zamorskich. Były to pierwsze kroki prowadzące do pomiaru ryzyka.

Początek powstania tej nowej dyscypliny łączy się z grami losowymi. W XVI wieku zaczęto zastanawiać się nad prawdopodobieństwem i przypadkowością. W XVII wieku teorią prawdopodobieństwa zainteresował się francuski uczony B. Pascal, który wspólnie z P. de Fermatem skonstruował metodę analizowania przyszłych zdarzeń. Procedura ta pozwalała wyznaczać prawdopodobieństwo możliwych wyników przy założeniu, że te wyniki są matematycznie mierzalne. Należy stwierdzić, że tylko człowiek nieroztropny podejmuje ryzyko w sytuacji, gdy reguły działania nie są jasno określone.

Pascal był matematykiem i filozofem. W 1654 roku przeżył mistyczne olśnienie i zaszył się w klasztorze Port Royal. Można przypuszczać, że nie porzucił on swoich zainteresowań naukowych. Grupa uczonych z Port Royal w 1662 roku opublikowała dzieło pt. Logika, czyli sztuka myślenia. Można w nim znaleźć fragment dotyczący pomiaru prawdopodobieństwa wyniku na przykładzie gry w monety. Naprawdę chodziło jednak o pewną analogię ze zdarzeniami zachodzącymi w przyrodzie. I tak, np. prawdopodobieństwo porażenia piorunem jest znikome, ale wielu ludzi żywi nadmierny lęk, słysząc grzmoty piorunów. Przy tej okazji sformułowana została uwaga o podstawowym znaczeniu: lęk przed niebezpieczeństwem powinien być proporcjonalny nie tylko do wielkości niebezpieczeństwa, ale także do prawdopodobieństwa, z jakim może ono nastąpić.

Zatem podejmowanie decyzji wymaga zarówno uwzględnienia siły, z jaką pragniemy osiągnąć konkretny rezultat jak i stopnia pewności dotyczącego prawdopodobieństwa uzyskania oczekiwanego wyniku. Siła naszych pragnień, którą zaczęto później określać mianem użyteczności, stała się kluczowym pojęciem wszystkich teorii podejmowania decyzji i podejmowania ryzyka. Przy okazji rozważań nad prawdopodobieństwem warto zwrócić uwagę na aspekt filozoficzny

\footnotetext{
5 Por. T. T. Kaczmarek, Ryzyko w handlu międzynarodowym, ODDK Gdańsk 2004.
} 
tych badań. Pascal w klasztorze Port Royal napisał książkę pt. Myśli, w której nawiązał do pewnej gry losowej, stawiając pytanie: jaką podjąć decyzję ? Jest to tzw. zakład Pascala, który zawiera się w pytaniu: Czy Bóg istnieje, czy też go nie ma? - Sprawa jest niezwykle złożona i rozum ludzki nie wiele może tu pomóc. Tak to narodziła się teoria decyzji. Teoria decyzji rozstrzyga, jak powinniśmy postąpić wówczas, kiedy nie mamy pewności co do przyszłego rozwoju wypadków i zdarzeń. Podjęcie decyzji w takich sytuacjach jest pierwszym nieodzownym krokiem w kierunku zarządzania ryzykiem. Jeżeli chodzi o istnienie Boga, to nie możemy przeprowadzić eksperymentu, który by udowodnił jego istnienie. Jedyna droga, którą rozporządzamy jest rozważenie przyszłych konsekwencji przyjęcia lub odrzucenia wiary w Boga. Równocześnie, nie możemy uchylić tego pytania, bo sam fakt, że żyjemy zmusza nas do wzięcia udziału w tej grze. ${ }^{6}$

\section{METODOLOGIA BADAŃ NAUKOWYCH W ZAKRESIE RYZYKA}

Rozważania nad ryzykiem koncentrowały się w na pojęciach wiedzy, poznania, niepewności oraz obiektywnym i subiektywnym podejściem do niego. Już w starożytności, dla Sokratesa istota nauki tkwiła w poznaniu i wiedzy. Przedmiotem poznania dla niego oprócz rzeczywistości zewnętrznej był człowiek jako istota, która powinna umiejętnie korzystać ze swego rozumu dla osiągnięcia pełni szczęścia. Dla Platona podstawą nauki były pojęcia, ponieważ zawarta w nich wiedza była pewna i obiektywna. Uważał, że przedmiotem pojęć nie mogą być rzeczy, lecz idee. Rozwijając teorię nauki uznał, że metody empiryczne, jakimi posługują się badacze dostarczają wiedzy niepewnej, ponieważ empirycznie można stwierdzić tylko przemijające fakty, nauka natomiast szuka prawd ponadczasowych.

Ważnym kryterium zaakceptowania wypracowanych metod i definicji jest zgodność uczonych co do przydatności, adekwatności i zgodności tych narzędzi z osiągniętymi wynikami badań. Dalszym krokiem jest dostosowanie metod badań nad ryzykiem do metod znanych z podręczników stosowanych w innych dyscyplinach naukowych. Narzędzia badawcze stosowane także przez innych badaczy posiadają bowiem wspólne cechy, zarówno jeżeli chodzi o metody jak i definicje. Bywa jednak, że występują trudności zwłaszcza wtedy, kiedy uzyskane wyniki pozostają w sprzeczności z wynikami uzyskanymi przy pomocy innych metod i narzędzi albo kiedy wręcz uniemożliwiają prowadzenie badań. Jednak uczony może odnieść sukces i osiągnąć założony cel, kiedy będzie dysponował odpowiednimi kryteriami prowadzenia badań. Badania nad ryzykiem dokonywały się w ramach trzech dyscyplin naukowych: nauk przyrodniczych, historyczno -hermeneutycznych i społecznych.

6 Zob. H. Jungermann, H.-R. Pfister, K. Fischer, Die Psychologie der Entscheidung. Eine Einführung, Heidelberg-Berlin, 1998, s.198. 
Stąd w tematyce risk management występuje połączenie wielu elementów występujących w wymienionych powyżej trzech grupach. W tym m.in. przejawia się interdyscyplinarny charakter badań prowadzonych nad ryzykiem, obejmujących prognozę, interakcję i determinanty ludzkich zachowań. Uczeni badający ryzyko, dysponują pojęciami, definicjami i metodami odpowiednimi dla badacza indywidualnego. W swej pracy naukowej koncentrują oni swoją uwagę na formalnych aspektach badań, a ponadto stosują metody badawcze zgodnie z ogólnie przyjętymi kryteriami. Interdyscyplinarność metodologiczna badań nad ryzykiem przyczynia się do podnoszenia jakości wyników tych badań, ale jednocześnie może utrudniać i wydłużać sam proces badawczy.

Metodyka ustala, co należy brać pod uwagę, aby zbadać określony rodzaj ryzyka, a w metodologii poszukuje się argumentów dla uzasadnienia, dlaczego dane ryzyko powoduje takie a nie inne skutki. Zmierza ona do ustalenia i objaśnienia kryteriów, w oparciu o które rozstrzyga się o identyfikacji i szczegółowych właściwościach różnych rodzajów ryzyka. Ponadto, do metodologii należy weryfikowanie, porównywanie i systematyzowanie przyjętych strategii badawczych.

Naukowcy zajmujący się ryzykiem prowadzą badania, studiując i rozwijając dorobek poprzedników. ${ }^{7}$ Metodologia ryzyka nie została dotychczas przedstawiona na poziomie meta. Gdyby jednak podjąć taką próbę, to mogłoby się okazać, że brak jest niezbędnych narzędzi. W teorii nauki nie zdołano dotąd opracować spójnego warsztatu badawczego odpowiedniego dla badań w tej dziedzinie. Stosowana w naukach przyrodniczych ogólna metodologia teorii nauki zakładająca, że istnieje ta sama wspólna metodologia badawcza, doprowadziła do licznych sporów oraz powstania wielu szkół, do których można zaliczyć m.in. Poppera, Kuhna i Lakatosa. Klasyczna teoria naukowego poznania jest ukierunkowana na badanie mechanicznego obrazu świata, zajmuje się opisem empirycznym przedmiotów przestrzennych, ich miejscem w przestrzeni oraz pierwotnymi cechami i właściwościami, czyli kształtem, wielkością i masą. Takie podejście jest jednak mało użyteczne w badaniu ryzyka, które wymaga odmiennego dynamicznego i interdyscyplinarnego podejścia. Ryzyko charakteryzuje się nieco innymi właściwościami i podlega stałym zmianom. Zależy ono od uwarunkowań, w jakich występuje co niesie określone konsekwencje teoretyczne i poznawcze dla badań nad ryzykiem. Warto też zauważyć, że obszar ryzyka wymyka się niekiedy niektórym prawidłom i zasadom logiki. ${ }^{8}$

7 Por. Th. S. Kuhn, Struktura rewolucji naukowych, Warszawa 2009, s. 17 i nast.

8 Por. P. L. Berstein, Przeciw bogom. Niezwykte dzieje ryzyka, WIGPRESS Warszawa 1997, passim. 


\section{W POSZUKIWANIU PEWNOŚCI}

Wiele decyzji jest podejmowanych przy niepełnych danych. Chcąc przewidzieć bieg przyszłych zdarzeń odwołujemy się zwykle do doświadczeń lub próbek, które stanowią wielkość przeciętną lub uśrednioną. Prognozowanie przyszłości w XVII wieku stało się bezwzględną koniecznością dla odważnych przedsiębiorców. Stało się ono także jedną z najbardziej doniosłych innowacji w nauce ekonomii. Przejście od ustalania zdeterminowanych prawdopodobieństw matematycznych do szacowania prawdopodobieństwa niepewnych zdarzen - wymagało przezwyciężenia wielu barier.

Początek XVIII wieku przyniósł nowatorskie idee braci Bernoullich, a w tym teorię użyteczności. Teoria ta stawiała wymagania, aby osoba rozumna była w stanie mierzyć użyteczność w każdych okolicznościach, a także dokonywać wyboru i podejmować decyzje zgodnie z tą miarą użyteczności. Nie jest to jednak łatwe zadanie, ponieważ w wielu sytuacjach fakty nie są identyczne dla każdej jednostki. Jednocześnie poszczególne osoby nie dysponują identycznym zasobem informacji, a każda z nich nadaje informacjom inne znaczenie. Nawet najbardziej racjonalni ludzie spierają się niekiedy o znaczenie tych samych faktów.

Teorii prawdopodobieństwa stała się ważnym narzędziem prognozowania przyszłości. Jednym z pierwszych badaczy, którzy zajęli się związkami istniejącymi między prawdopodobieństwem a jakością informacji był Jakub Bernoullie. ${ }^{9}$ W 1703 roku postawił on pytanie, jak można ustalić prawdopodobieństwo na podstawie wyrywkowych danych. Na ten temat Jakub Bernoulli prowadził ożywioną dyskusję z G. Leibnitzem, który m.in. zauważył, że przyroda ustanawia prawidłowości, które mają swoje źródło w powtarzalności zdarzeń, przy czym odnoszą się tylko do większości przypadków. Można więc postawić pytanie: czy możemy dysponować wszystkimi potrzebnymi informacjami? Bernoulli wniósł istotny wkład w rozwiązanie kwestii wyprowadzania prawdopodobieństw z ograniczonych zasobów informacji, dostępnych w realnym życiu. Zasugerował rozwiązania wymagające przyjęcia założenia, że w podobnych warunkach, występowanie lub niewystępowanie pewnego zdarzenia w przyszłości będzie odpowiadało tym samym prawidłowościom, które zostały zaobserwowane w przeszłości. Od trafności przyjętych założeń zależy na ile skutecznie możemy wykorzystać pomiar i informację do prognozowania przyszłości. Dalsze badania kontynuował jego kuzyn Bernoulliego - Mikołaj wspólnie z Abrahamem de Moivrem, który uważał, że przy sprzyjających okolicznościach pomiar pozwoli nam istotnie zapanować nad niepewnością i poskromić ryzyko. De Moivre opracował matematyczne narzędzie, które umożliwiło szacowanie prawdopodobieństwa. ${ }^{10}$

${ }^{9}$ Szerzej: G. Shafer,The Significance of Jacob Bernoulli's Ars Conjectandi for the Philosophy of Probability Today, „Journal of Econometrics”, 75 (1), 1996, s. 15-32.

${ }^{10}$ J. Brakel, Some Remarks on the Prehistory of the Concept of Statistical Probability, [w:] „Archive for History of Exact Sciences”, 16 (2), Heidelberg, 1976, s. 119. 
W kolejnych dekadach doskonalono narzędzia pomiaru ryzyka w celu opanowania niepewności. Badania były prowadzone $\mathrm{m}$. in. przez F. Galtona (1822-1911). Wiedza, jaką udało mu się uzyskać oraz kilku innym badaczom, doprowadziły do powstania złożonych instrumentów pomiaru i kontroli ryzyka, które znajdują współcześnie zastosowanie w zarządzaniu ryzykiem finansowym przedsiębiorstw. Galton przekształcił statyczne pojęcie prawdopodobieństwa, które opierało się na losowości i prawie wielkich liczb, w proces dynamiczny. Zmiana i ruch od stanów skrajnych ku środkowi są stałe, nieuchronne i przewidywalne. $Z$ uwagi na nieusuwalne uwarunkowania tego procesu żaden inny rezultat poza rozkładem normalnym nie jest możliwy. Siła napędowa tego procesu jest zawsze skierowana w stronę wartości przeciętnej i przywrócenia stanu normalnego. Regresja do średniej leży u podstaw prawie każdej formy podejmowania ryzyka i prognozowania przyszłości. Należy jednak zauważyć, że regresja do średniej może okazać się zawodną wskazówką w podejmowaniu decyzji. Regresja może bowiem być tak silna, że rzeczy nie pozostaną w spoczynku z chwilą, gdy osiągną próg wartości przeciętnej. Najczęściej oscylują one wokół średniej, nieregularnie odchylając się w obu kierunkach. Ponadto sama średnia nie musi być wartością stałą, tak że wczorajsza norma może ustąpić dzisiaj miejsca nowej normie, o której nic nie wiadomo.

P. L. Bernstein po przeanalizowaniu wielu interesujących przypadków z przeszłości, doszedł do ważnej i równocześnie ostrożnej konkluzji. ${ }^{11}$ Stwierdził, że cała sztuka polega na tym, aby uświadomić sobie, że regresja do średniej jest tylko narzędziem, a nie zamkniętym systemem. Kiedy używa się jej do ekstrapolacji przeszłości w przyszłość, traci ona swoją wiarygodność. Nie należy liczyć na to, że regresja do średniej wpłynie na bieg wypadków, zwłaszcza, jeżeli stale nie będzie analizowana i weryfikowana zasadność przyjętych założeń, na których została oparta. F. Galton słusznie więc doradzał, aby nie bazować na wartości przeciętnej, lecz wszechstronnie badać zjawiska. ${ }^{12}$

\section{O POTRZEBIE BADANIA I MIERZENIA RYZYKA}

Podejmując ryzyko oczekuje się zazwyczaj określonego skutku. Nie ma jednak pewności, że uda się osiągnąć ten zamierzony. Nie mniej w decyzjach obarczonych ryzykiem zazwyczaj podejmowane są działania, aby na nie wpływać i kontrolować przebieg określonego zdarzenia. Koncepcję przyczyny i skutku rozwinął J. H. Poincare. Uważał on, że bez ich wszystkie zdarzenia pogrążone byłyby w chaosie, a nawet stałyby się skutkiem chaosu. Jedynie znajomość przyczyny pozwala w większym stopniu przewidzieć skutek, jednak nie da się do końca przewidzieć wszystkich konsekwencji. Niektóre zdarzenia, jawiące się jako zupełnie przypad-

${ }^{11}$ P. L. Bernstein, op. cit.

${ }^{12}$ Z. Hellwig, Elementy rachunku prawdopodobieństwa i statystyki matematycznej, Wyd. Naukowe PWN Warszawa 1998, s. 125 i nast. 
kowe mogą takimi nie być, a ich przyczyny są po prostu trudne do uchwycenia. Trudne do ustalenia drobne zmiany mogą powodować ogromne skutki. Nasuwa się pytanie: jak precyzyjnych narzędzi potrzeba, aby te przyczyny wykryć?

Zarówno Laplace jak i Poincare dostrzegali trudności związane ze zdobywaniem odpowiednich informacji niezbędnych przy korzystaniu z praw rachunku prawdopodobieństwa. Nie istnieje możliwość dotarcia i zgromadzenia wszystkich informacji przed podjęciem decyzji. Nie można również poznać do końca prawdziwa wartość informacji i ich rzetelność lub obiektywność. Stąd częstym mechanizmem podejmowania decyzji jest opieranie się na sprawdzonych schematach działania lub intuicji. Większość informacji, które posiadamy jest zwykle niepełna i niekompletna stąd powinny być stale uzupełniane. W warunkach niepewności nie wybiera się pomiędzy odrzuceniem a przyjęciem hipotezy, lecz między jej odrzuceniem lub nieodrzuceniem. Jednak w sytuacji, kiedy prawdopodobieństwo popełnienia pomyłki jest większe od zera, danej hipotezy nie należy przyjąć. Nie ma możliwości ustalenia bezpiecznego stopnia niepewności, lecz za każdym razem należy decydować, jaki poziom niepewności może być zaakceptowany.

W 1921 w. F. Knight opublikował pracę pt. Risk, Uncertainty and Profit, w której zajął się podejmowaniem decyzji w warunkach niepewności. U podstaw jego analizy znalazło się rozróżnienie pomiędzy ryzykiem a niepewnością. Jednoznacznie stwierdził, że niepewność była mylona z ryzykiem, tymczasem ryzyko jest kategorią mierzalną, natomiast niepewność nie. Knight twierdził, że rachunek prawdopodobieństwa jest zawodny, gdy chodzi o odzwierciedlenie twórczej natury umysłu ludzkiego w obliczu tego, co niepewne. F. Knight uznał, że trudność przewidywania przyszłości wykracza poza niemożność stosowania formuł matematycznych. Jego zdaniem, aprioryczne rozumowanie nie jest w stanie wyeliminować z przyszłości czynnika nieokreśloności. Na koniec konkludował, że poleganie na wnioskach wyciągniętych z obserwacji częstotliwości występowania zdarzeń w przeszłości jest wyjątkowo ryzykowne. F. Knight zauważył, że przedsiębiorcy prognozują przyszłe zdarzenia w oparciu o informacje z przeszłości i zwykle nie potrafią rozpoznać momentu, w którym warunki zaczynają się pogarszać lub poprawiać. Reagować zaczynają wówczas, kiedy pojawiają się negatywne zjawiska. W świecie biznesu dominuje element zaskoczenia. Dla Knighta istotnym powodem braku takiej możliwości jest to, że każde zdarzenie jest tak bardzo wyjątkowe, że w rzeczywistości nie ma dwóch takich samych zdarzeń lub liczba identycznych zdarzeń jest tak mała, że nie uda się ich uporządkować w sposób umożliwiający oszacowanie wartości rzeczywistego prawdopodobieństwa dla przypadku, który nas interesuje. To samo odnosi się do innych rodzajów aktywności, nie tylko biznesowych. ${ }^{13}$

Prawdopodobieństwo odnosi się do dużej liczby niezależnych obserwacji, dotyczących jednorodnych zdarzeń, takich jak np. rzuty kostką do gry. Natomiast, zdaniem Knighta, nigdy dotychczas nie wystąpiły dwa identyczne zdarzenia i nigdy

${ }^{13}$ Por. F. Knight, Risk, Uncertainty and Profit, New York 1964, s. 226. 
nie wystąpią. Można natomiast ogłaszać prognozy, że jakieś zjawisko w przyszłości się powtórzy z prawdopodobieństwem kilkudziesięciu procent. Błędy, jakimi są obciążone prognozy należy odróżniać od prawdopodobieństwa lub szansy. Utożsamianie prawdopodobieństwa, w sensie przedmiotowym z pewnością, jest pozbawione sensu i prowadzi do licznych nieporozumien. ${ }^{14} \mathrm{~W}$ szczególności można to odnieść do rynków finansowych, gdzie wszystkie decyzje odnoszą się do przyszłości, która jest trudno przewidywalna. Zmienność cen akcji i obligacji dowodzi, jak często oczekiwania są błędne i inwestorzy się mylą. Zmienność cen jest pochodną niepewności i musi być uwzględniana przy ocenie ryzyka inwestycyjnego.

Nie wdając się w szczegóły koncepcji ekonomicznej Keynesa, tworzącego w tym samym czasie co Knight, warto odnotować, że odnosił się on z pogardą do prawa wielkich liczb. Jego zdaniem fakt, że podobne do siebie zdarzenia występowały w przeszłości, wcale nie świadczy o tym, że powtórzą się one w przyszłości. Warunki gospodarcze podlegają ciągłym zmianom i dlatego wszelkie dane mają zastosowanie tylko do okresu, z którego pochodzą. W związku z tym stanowią one bardzo wątpliwą podstawę dla jakichkolwiek uogólnień. Przewidywanie zdarzeń przyszłych w oparciu o informacje z przeszłości może polegać na manipulacji. Według Keynesa nie istnieje taka gospodarka, w której przeszłość, teraźniejszość i przyszłość łączyłyby się w jedność. Raz podjęta decyzja stwarza zupełnie nowe warunki, które uniemożliwiają powrót do poprzedniego stanu. Podejmując decyzje naprawdę zmieniamy świat. Światem rządzi nie tyle matematyczne prawdopodobieństwo, ile niepewność. ${ }^{15}$

\section{RACJONALIZACJA PODEJŚCIA DO RYZYKA}

John von Neumann, wybitny fizyk i matematyk, swoją teorię gier strategicznych przedstawił w 1926 roku na forum Towarzystwa Matematycznego w Getyndze, a praca została opublikowana w 1928 roku. Według niego przegrana wynika z każdej strategii, której celem jest zwycięstwo, nie zaś uniknięcie przegranej. Bernstein zauważa, że po raz pierwszy von Neuman mówi o prawdopodobieństwie przegrania jako o integralnej części zarządzania ryzykiem. ${ }^{16}$ Wraz z Oskarem Morgensternem wspólnie przez kilka lat kontynuowali badania, które opublikowali w książce Theory of Games and Economic Behavior. Praca dotyczyła teorii gier i zastosowania jej w procesie podejmowania decyzji w całej gospodarce jak i w poszczególnych przedsiębiorstwach. Uczeni dokonali analizy przypadku osoby, która stanęła przed wyborem jednej z dwóch możliwości, podobnie jak w sytuacji wyboru pomiędzy orłem i reszką w grze w monety. Następnie zmieniali kolejność preferencji wyboru i uwzględniali stopień satysfakcji podmiotów

\footnotetext{
${ }^{14}$ Ibidem, s. 227.

${ }^{15}$ Por. J. M. Keynes, Treatise on Probability, N. York 1921, passim.

${ }^{16}$ P. L. Bernstein, op. cit., s. 210.
} 
dokonujących wyboru. Oparli oni swoją pracę na jednym zasadniczym elemencie zachowania, a mianowicie zwycięstwie przypadającym osobie, która maksymalizuje swoją użyteczność.

W 1952 roku w Journal of Finance został opublikowany artykuł pt. Dobór portfela, którego autorem był Harry Markowitz. ${ }^{17}$ Głównym założeniem artykułu była teza, że portfel papierów wartościowych rządzi się zupełnie innymi prawami niż poszczególne papiery wartościowe rozpatrywane $\mathrm{z}$ osobna. Postrzegał on inwestorów jako podmioty dokonujące racjonalnych wyborów. Markowitz posłużył się programowaniem liniowym, do którego rozwoju w ogromnym stopniu przyczynił się von Neumann. ${ }^{18}$ Wykorzystał on czynnik ryzyka w konstruowaniu portfeli dla inwestorów, którzy postrzegali oczekiwaną stopę zwrotu jako rzecz pożądaną oraz wariancję stopy zwrotu jako efekt niepożądany. Jego teoria została zbudowana na połączeniu stopy zwrotu $\mathrm{z}$ wariancją. ${ }^{19}$ Przedstawiając przygotowaną przez siebie strategię inwestycyjną Markowitz nie użył słowa ryzyko, natomiast wprost określił wariancję stopy zwrotu jako zjawisko niepożądane, której wielkość inwestor chce zminimalizować. Ryzyko i wariancja są u niego synonimami. Można powiedzieć, że von Neumann i Morgenstern zmierzyli użyteczność, natomiast Markovitz zmierzył ryzyko inwestycyjne.

Markovitz przywiązywał ogromną wagę do dywersyfikacji portfela. Zastosowanie dywersyfikacji do redukcji zmienności jest zgodne z naturalnym, cechującym się awersją do ryzyka i dążeniem do tego, co jest pewne, a unikaniem tego, co nie jest pewne. Podkreślał, że gros inwestorów wybiera niższą oczekiwaną stopę zwrotu, jaką przynieść może zdywersyfikowany portfel inwestycyjny, zamiast stawiać wszystko na jedną kartę i dokonać bardziej ryzykownego wyboru w nadziei na większy zysk, zastępując przeczucia dotyczące niepewności - miarą statystyczną, Markowitz dokonał zmiany tradycyjnego sposobu doboru akcji w dość precyzyjną procedurę wyboru portfeli „efektywnych”. Określenie „efektywny” zarezerwował on dla portfeli łączących najlepsze akcje przy danej cenie z najmniejszą wariancją. Oznacza to, że bez ryzyka nie ma zysku, ale nie należy wszystkiego stawiać na jedną kartę. Równocześnie warto zauważyć, że nie istnieje jeden efektywny portfel, który byłby bardziej efektywny niż wszystkie pozostałe. Metoda Markowitza dzięki programowaniu liniowemu pozwala uzyskać obszerny katalog portfeli

${ }^{17}$ Oryginalność Markovitza przejawiła się m.in. w tym, że w swoim artykule zrezygnował z przypisów, odnośników i danych bibliograficznych. W ten sposób naraził się wielu „uczonym”, których „naukowość” przejawiała się i niekiedy jeszcze przejawia się, w przesadnym powołaniu się na różne źródła, najczęściej wcale nie oryginalne ani też pierwotne.

${ }^{18}$ Programowanie liniowe jest metodą pozwalającą na opracowywanie modeli matematycznych, dotyczących minimalizacji kosztów przy stałej wielkości produkcji lub maksymalizacji produkcji przy stałych kosztach.

${ }^{19}$ Wariancja jest wielkością statystyczną pokazującą, jak stopy zwrotu z aktywów odchylają się od wartości średniej. Z matematycznego punktu widzenia miara ta łączy się z odchyleniem standardowym i w praktyce oba te pojęcia są stosowane zamiennie. Im większa wariancja lub odchylenie standardowe względem średniej, tym mniej możemy polegać na średniej stopie zwrotu jako wyznaczniku prawdopodobnego wyniku. 
efektywnych. Im większa jest oczekiwana stopa zwrotu, tym wyższe jest ryzyko. Opisywany dobór portfela radykalnie zmienił więc pracę osób odpowiedzialnych za zarządzanie inwestycjami. Jednak Markowitz zdawał sobie sprawę z trudności związanych z próbą praktycznego zastosowania opracowanej koncepcji.

Przy uwzględnieniu czynnika czasu relacje pomiędzy ryzykiem i zmiennością zaczynają zanikać. Zmienność jest raczej szansą niż ryzykiem, bo to co traci na wartości, kiedyś może zyskać. Ryzyko należy badać w stosunku do pewnego punktu odniesienia lub pewnej minimalnej stopy zwrotu, którą inwestor chce przekroczyć. Jeżeli ryzyko stanowi okazję do stracenia pieniędzy, to nominalnie zerowa stopa zwrotu stanowi punkt odniesienia dla inwestora, który podejmuje się zadania zbudowania portfeli minimalizujących prawdopodobieństwo uzyskania ujemnej stopy zwrotu w danym okresie. Takie podejście wykracza jednak poza teorię Markowitza. Teoria Markowitza została poddana krytyce, co przyczyniło się do powstania nowych koncepcji oraz nowych zastosowań, które pewnie nigdy nie pojawiłyby się, gdyby nie jego nowatorska koncepcja.

\section{NOWE TENDENCJE I KIERUNKI BADAŃ NAD RYZYKIEM}

Badania prowadzone nad zdywersyfikowanym ryzykiem w drugiej połowie lat 90. XX wieku i na początku XXI wieku cechuje coraz intensywniejsze łączenie ryzyka ze środowiskiem naturalnym. Na pierwszy plan wysuwa się relacja: człowiek - środowisko oraz zmiany w środowisku. Ważna staje się koncepcja ryzyka i działania w warunkach narastającej niepewności przyszłych zdarzeń, przy czym najważniejsza jest globalna perspektywa i ryzyko związane z środowiskiem człowieka. Ponadto badania nad ryzykiem cechuje świadomość społecznego podejścia oraz wielowarstwowość tej problematyki, a także konieczność podejścia interdyscyplinarnego. Pomimo tej świadomości, nie zdołano dotychczas opracować jednej koncepcji badawczej ryzyka i jego uniwersalnej definicji. Co więcej, dziedzina badań prowadzonych nad ryzykiem jest niekiedy obszarem formułowania sprzecznych paradygmatów badawczych, rozbieżnych celów i ocen. Takie krytyczne podejście powinno jednak w perspektywie doprowadzić do pozytywnych rozwiązań z korzyścią dla człowieka i jego środowiska.

Do spornych obszarów badań nad ryzykiem należy zaliczyć:

- kwestię podejścia do nowych technologii, do zagrożeń i sposobów ich opanowania,

- odpowiedzialność za podejmowane decyzje obciążone ryzykiem,

- realizację decyzji obciążonych ryzykiem i sposób ich wyjaśniania,

- politykę wobec ryzyka,

- kwestię trudnych do skalkulowania zagrożeń i możliwość ich ograniczenia,

- zagadnienie konieczności i możliwości dostosowania zmian środowiska społecznego do narastającego ryzyka, np. budowa potężnej tamy w Chinach, która spowoduje ogromne zmiany ekologiczne. 
W celu przedstawienia współczesnego podejścia do badań nad zdywersyfikowanym ryzykiem przedstawione zostaną wybrane kwestie, które dotyczą analizy globalnych zmian w świecie współczesnym z różnych perspektyw. W tym kontekście interesujący jest amerykański raport zatytułowany: The Human Choice and Climate Change (HCCC) ${ }^{20}$, który stanowi istotne uzupełnienie badań prowadzonych nad zmianami klimatycznymi w świecie. ${ }^{21}$

Raport klimatycznego opiera się na założeniu, że ingerencje człowieka w system przyrody powodują zagrożenia wielkiej skali, które z racji swego globalnego zasięgu i nieodwracalności zmian, wymagają opracowania konkretnych strategii obronnych, a zwłaszcza mechanizmu wczesnego ostrzegania. Z uwagi na to, że nie istnieje prosta możliwość zabezpieczenia się przed globalnym ryzykiem, potrzebna jest spójna polityka zapobiegania im w wielu państwach. Nie jest to łatwe zadanie, ponieważ wywoływane przez działalność produkcyjną człowieka negatywne skutki można jednoznacznie ocenić dopiero po 50 a nawet 100 latach. $Z$ drugiej strony, bez gotowości człowieka do podejmowania ryzyka nie jest możliwe dokonywanie wielu innowacji, a bez innowacji nie zostaną rozwiązane globalne problemy gospodarcze i ekologiczne. Trzeba zatem działać z rozwagą i ostrożnością.

Mając na uwadze ograniczone możliwości rozwiązania tego problemu przez naukę, należy odradzać politykom stosowania tradycyjnej metody prób i błędów w odniesieniu do nowych rodzajów zagrożeń i ryzyka. Możliwość prowadzenia empirycznych badań nad skutkami globalnego ryzyka praktycznie nie istnieje. Niepewne są też efekty działań polityków w warunkach braku spójnej polityki ochrony środowiska. Prowadzona jest ona w warunkach niepewności, nieokreśloności, co jednak nie wyklucza konieczności opracowania i stosowania konkretnych norm etycznych. Należy tu ponadto uwzględnić brak występowania w ekologii liniowych łańcuchów przyczynowo-skutkowych oraz dobrych narzędzi modelowania i symulowania zdarzeń w tym obszarze. Zatem naukowe prognozy w dużym stopniu są niepewne i wieloznaczne.

Pomimo wspomnianych ograniczeń istnieje przekonanie specjalistów, że uda się przy pomocy systemowej analizy ocenić i zmierzyć ryzyko związane z globalnymi przemianami, aby następnie je skutecznie ograniczyć przy pomocy narzędzi risk management. Do podstawowych elementów systemowej analizy zarządzania ryzykiem można zaliczyć:

- wyróżnienie specyficznych typów ryzyka w oparciu o prawdopodobieństwo ich wystąpienia i wielkość wywołanych szkód, a także stopień pewności ich wyceny,

${ }^{20}$ Welt im Wandel - Strategien zur Bewältigung globaler Umweltrisiken, Hauptgutachten 1998 Wissenschaftlicher Beirat der Bundesregierung Globale Umweltveränderungen, Springer-Verlag, Berlin, 1999, XXIV, Vollversion: 378.

${ }^{21}$ Istotne aspekty tego obszaru ryzyka przedstawiłem po raz pierwszy w książce pt. Zarzadzanie zdywersyfikowanym ryzykiem w świetle badań interdyscyplinarnych. Typologia i semantyka, Wydawnictwo WSZiM Warszawa 2003. 
- analizę przyczyn, warunków brzegowych i rodzajów ryzyka oraz następstw ich regionalnej specyfiki w interakcji: człowiek - przyroda zmiany, 22

- naukową ocenę zaistniałego ryzyka przez przyporządkowanie go do określonego typu ryzyka,

- przyjęte strategie działania oraz podejmowane decyzje,

- zalecenia zmierzające do doskonalenia metod sterowania ryzykiem (adekwatne narzędzia),

- wskazówki, jak zarządzać nieznanymi rodzajami ryzyka.

Jakkolwiek koncepcja ta mocno nawiązuje do tradycyjnego podejścia do zarządzania ryzykiem, to jednak stara się zobiektywizować ryzyko przez naukową jego ocenę, racjonalne zarządzanie nim i stosowanie adekwatnych narzędzi.

Spory wokół ryzyka prowadzone są w kontekście subiektywnego pojmowania ryzyka i jego komunikowania (objaśniania i wskazywania sposobów odpowiednich zachowań), przy czym zwraca się uwagę na odmienne kompetencje i intencje ekspertów oraz laików. Globalne ryzyko wymaga obywateli świadomych ryzyka, przy czym ocena ryzyka i określenie stopnia jego akceptowalności należy do nauki, która dostarcza odpowiednich sposobów postępowania. Oceny ryzyka dokonuje się przy wykorzystaniu odpowiednich metod i wzorów matematycznych. Analiza czynników indywidualnych, społecznych i kulturowych, które pozwalają określić subiektywne ryzyko, umożliwia zrozumienie różnicy między ryzykiem obiektywnym i subiektywnym.

Autorzy raportu The Human Choice and Climate Change $(H C C C)^{23}$, podobnie jak autorzy raportów narodowych, uwzględniają nową jakość potencjału zagrożeń w kontekście globalnych zagrożeń. Wspólne dla wszystkich badaczy jest znaczenie, jakie przywiązują do interdyscyplinarnych badań zmierzających do rozwiązania istniejących problemów. Ponadto zwracają uwagę na polityczne znaczenie i użyteczność wniosków, wynikających z raportów.

$\mathrm{W}$ raporcie HCCC badania zostały przeprowadzone z uwzględnieniem metodologii nauk społecznych. W centrum uwagi nie znalazło się pojęcie mierzalnego ryzyka technicznego, lecz zagadnienie ludzkich działań w warunkach niepewności, w obliczu nowych zagrożeń. ${ }^{24}$ Nauki przyrodnicze nie potrafią przewidzieć działań, które należy podjąć w sytuacji, kiedy nawet udałoby się dokładnie przewidzieć dynamikę i skutki zmian klimatycznych. Z punktu widzenia nauk społecznych stwierdza się istnienie „społecznej świadomości”, która pobudza ludzi do stałej refleksji nad społecznymi uwarunkowaniami dokonujących się zmian.

W pierwszym tomie pt. The Social Framework, czterotomowego raportu, zawarta została analiza społecznych, kulturowych, politycznych i ekonomicz-

${ }^{22}$ Analiza ryzyka i syndromu: człowiek - przyroda - zmiany, pozwala na naukową chociaż wycinkową ocenę rozwoju ryzyka w społeczeństwie, środowisku i technice.

${ }^{23}$ Por. The Human Choice and Climate Change (HCCC), Columbus, Ohio, Batelle Press 1998.

${ }^{24}$ The Human Choice and Climate Change (HCCC), Columbus, Ohio, Batelle Press 1998, s. 26. 
nych systemów w kontekście dokonujących się globalnych przemian. Autorzy skoncentrowali uwagę na interakcji pomiędzy nauką, polityką i społeczeństwem, a także na związku występującym pomiędzy dynamiką ludnościową i zmianami klimatu. Następna kwestia przedstawiona w raporcie, to koncepcja sprawiedliwości, która kieruje się determinantami społecznymi i instytucjonalnymi.

$\mathrm{W}$ drugim tomie pt. Resources and Technology zostały poddane analizie zmiany klimatyczne oraz zachowania człowieka w trakcie korzystania z takich globalnych zasobów jak ziemia, woda, oceany i wybrzeża. Zbadano także zależność ilości zużywanej energii od struktur przemysłowych i społecznych oraz wprowadzanych zmian technologicznych. W świetle przeprowadzonych badań wykazano negatywny wpływ działalności ludzkiej na zmiany klimatyczne. Autorzy raportu zauważyli, że zmiany klimatyczne nie stanowią jednak najważniejszego czynnika wpływającego na wykorzystanie zasobów wodnych i ziemi.

W trzecim tomie pt. The Tools for Policy Analysis przeanalizowane zostały tradycyjne instrumenty zarządzania ryzykiem i ocenione pod kątem ich skuteczności w rozwiązywaniu problemów zmian klimatycznych. Najpierw zbadano skuteczność ekonomicznej analizy pod kątem jej praktycznego znaczenia i możliwych ograniczeń. Punktem wyjścia we wszystkich analizach ekonomicznych była jednostka (człowiek) podejmująca racjonalne decyzje. Zbadano, w jakim stopniu paradygmat rational choice może zostać dostosowany do podejmowania decyzji na poziomie państwa i w skali międzynarodowej, przy wykorzystaniu technik symulacji i teorii gier. Ponadto autorzy zbadali implikacje dla kwestii ochrony środowiska, wynikające $\mathrm{z}$ rozdzielenia w tym paradygmacie racjonalności od wartości. $\mathrm{Na}$ koniec zajęli się ograniczeniami płynącymi z różnych narzędzi modelowania, a zwłaszcza potencjału integrated risk assessment. We wnioskach zwrócono uwagę na normatywny wymiar dominującej koncepcji racjonalności oraz jej ograniczone znaczenie w odniesieniu do analizy, oceny i radzenia sobie ze zjawiskiem globalnych przemian.

$\mathrm{W}$ czwartym tomie pt. What have we learned? zawarta została synteza przeprowadzonych badań i postawione zostało pytanie, w jakim stopniu konfrontacja ze zjawiskiem zmian klimatycznych stanowi wyzwanie dla nauk społecznych i jakie zalecenia wynikają dla decydentów z przeprowadzonej analizy. Wyeksponowano konieczność odpowiedzialnej kooperacji socjologów z politykami w znalezieniu rozstrzygnięcia kwestii dynamiki przemian społecznych oraz ustalenia znaczenia lokalnych rozwiązań dla realizacji globalnych celów w odniesieniu do środowiska i społeczeństwa.

Na pierwszym miejscu w raporcie znalazła się kwestia działania jednostki i podejmowania bieżących decyzji w warunkach niepewności oraz problematyka dotycząca przyszłych decyzji obciążonych dużym ryzykiem. Dalsze kwestie dotyczyły świadomych i nieuświadomionych warunków działalności człowieka, a także społecznej odpowiedzialności związanej z naukowymi badaniami. $\mathrm{Z}$ tej perspektywy można by zakwestionować obiektywizm badania i oceniania ryzyka. 


\section{OBIEKTYWIZM BADAŃ PROWADZONYCH NAD RYZYKIEM}

W badaniach prowadzonych nad ryzykiem można wyróżnić dwie postawy: pierwszą - podejście obiektywne i drugą - wątpienie metodyczne, czyli podejście refleksyjne. W przedstawionych powyżej raportach te dwie postawy znalazły zastosowanie. W pierwszym podjęta została próba opisania i wyjaśnienia rzeczywistości przy wykorzystaniu probabilistycznego pojęcia ryzyka według tradycyjnej koncepcji quasi-deterministycznej, a w raporcie zwrócono uwagę na aspekt niepewności i zmian w badanej rzeczywistości.

Podejście obiektywne opiera się o pojęcie człowieka racjonalnego, czyli homo oeconomicus, natomiast podejście refleksyjne, dostrzegając pewien deficyt tej postawy uniemożliwiającej kompleksowe opisanie rzeczywistości, uważa że nie nadaje się ono do wyjaśnienia zachowań jednostki ludzkiej. Nauki społeczne pełnią funkcję pomocniczą, natomiast nauki ścisłe są najbardziej skuteczne w rozwiązywaniu problemów związanych z ryzykiem i środowiskiem. Podejście obiektywne wychodzi z założenia, że istnieje możliwość poznania obiektywnej rzeczywistości, i że jest to najważniejsze zadanie, zwłaszcza dla nauk ścisłych. Badanej rzeczywistości przyznaje się priorytet $\mathrm{i}$ jest ona podstawą do prowadzenia racjonalnej polityki społecznej. Podstawowym zadaniem nauki jest $\mathrm{w}$ tym ujęciu analiza społecznych konstrukcji obiektywnej rzeczywistości.

Pomimo braku spójności, a nawet sprzeczności występujących w przedstawionych wyżej koncepcjach, można w nich jednak znaleźć pewne podobieństwa. Jednej i drugiej, przepisuje się ważną rolę w rozwiązywaniu prezentowanej wyżej problematyki, a do ryzyka podchodzi się z optymizmem. W podejściu obiektywnym wykorzystywane są ulepszone narzędzia analizy i oceny nowych rodzajów ryzyka, a postęp technologiczny ma dostarczać narzędzi niezbędnych do skutecznego pokonania nowych zagrożeń.

W podejściu pesymistycznym występuje sceptycyzm i powątpiewanie co do skuteczności sił samouzdrowieńczych, tkwiących w technice i systemach społecznych. Powątpiewa się również w pozytywną rolę nauki. W ideologii postępu i wzrostu gospodarczego państw uprzemysłowionych pesymiści dopatrują się źródeł ryzyka i zagrożeń dla środowiska, a nawet uważają, że należy odejść od paradygmatu nieograniczonego wzrostu gospodarczego i od nowa ustalić system wartości ekonomicznych i społecznych.

\section{EKSPLOZJA INFORMACJI I JEJ WPŁYW NA BADANIA NAD RYZYKIEM}

Badania nad ryzykiem prowadzone w ostatnim dziesięcioleciu dotyczą jego płaszczyzny indywidualnej, instytucjonalnej i społecznej. Kładzie się silny nacisk na konsekwencje materialne podejmowanych decyzji obciążonych ryzykiem. Natomiast na dalszym planie znajdują się możliwe skutki społeczne i kulturowe podjętych decyzji obciążonych ryzykiem. Należy zatem postulować konieczność 
podjęcia badań naukowych nad koncepcjami zachowań społecznych, których skutki dotyczą przyszłych pokoleń. Obserwuje się przecież w życiu prywatnym, zawodowym i społecznym zachowania i decyzje obciążone znacznym ryzykiem. Przy tym niezwykle trudno jest przewidzieć ich skutki, a są one tym bardziej niepewne, im bardziej odległy jest horyzont czasowy. Powstaje zatem pytanie, czy przyszłe społeczeństwo można ex ante dowolnie kształtować? I czy uda się je uwolnić od ryzyka?

Badając ryzyko należy próbować wpływać na los i kształt przyszłych zdarzeń, co nie jest łatwym zadaniem. Nie wiadomo, jakie wartości i cele, będzie przyszła generacja chciała zaakceptować. Wydaje się jednak, że strategia rozwoju społecznego w ujęciu globalnym, wymusi zachowania bardziej kompromisowe, które pozwolą naszej cywilizacji przetrwać.

Nauka, zdaniem niektórych badaczy, skupia się obecnie nie na badaniu podstawowych praw natury, lecz na praktycznych zastosowaniach, mając na uwadze zlecenia klientów i osiągnięcie określonych korzyści. ${ }^{25}$ Dyscypliny naukowe nie stanowią już ram formalnych dla badań. Uczeni mają dzisiaj możliwość prowadzenia badań interdyscyplinarnych, jak to ma miejsce w przypadku badań nad ryzykiem. Problemy te rozwiązywane są zwykle drogą eksperymentów, a wiedza transdyscyplinarna posiada własne struktury teoretyczne i metody badawcze. Uzyskiwane wyniki są przekazywane nie kanałami urzędowymi, lecz są od razu komunikowane uczestnikom procesu badawczego.

Post-normal Science oznacza jakościową zmianę w nauce i uważa się, że spowoduje ona rewolucję, powodując równocześnie zmianę definicji przedmiotu badania i metod badawczych. Zmiany instytucjonalne w nauce prawdopodobnie spowodują także zmiany epistemologiczne, które trudno jest w tej chwili określić.

Zmiany, o których mowa, najszybciej dokonują się w Stanach Zjednoczonych, gdzie przemysł współpracuje ściśle $\mathrm{z}$ uniwersytetami w formie podobnej do Venture Capital. Zakłady przemysłowe zyskują na elastyczności płacąc za badania (zwłaszcza podstawowe) uniwersytetom, nie muszą budować własnych laboratoriów u siebie, ani też angażować wysokopłatnych naukowców. ${ }^{26}$ Proces ten dokonuje się w ramach globalizacji badań. Wypada się jednak zastanowić nad tym, jakie konsekwencje w przyszłości będzie miało ingerowanie przemysłu w programy badawcze realizowane przez uniwersytety. Czy wartość akademickich badań straci na jakości i na znaczeniu? Czy pozostaną one obiektywne? ${ }^{27}$

W Polsce po 1989 roku powstało kilka instytutów i kilkadziesiąt firm doradczych, które jednak nie są przygotowane jeszcze do prowadzenia samodzielnych badań i korzystają często z badań prowadzonych na wyższych uczelniach

${ }^{25}$ M. Gibbons, The New Production of Knowledge, Cambridge MIT-Press 1994, s. 4 i nast.

${ }^{26} \mathrm{M}$. Zgorzelski, Hamburgery ze świętej krowy. Szkice o amerykańskiej teorii i praktyce zarządzania, Oficyna Ekonomiczna Kraków 2002.

${ }^{27}$ Taką drażliwą sprawą w płaszczyźnie moralnej i etycznej stały się badania genetyczne prowadzone na niektórych uniwersytetach amerykańskich finansowanych przez przemysł. 
państwowych i prywatnych oraz na uniwersytetach. Podobna sytuacja panuje we Francji i w Niemczech, gdzie badania dotyczące nauk przyrodniczych objęte są współpracą z przemysłem, natomiast nauki humanistyczne pozostają tradycyjnie w uniwersytetach.

Rosnące znaczenie badań transdyscyplinarnych łączy się z przedstawionymi powyżej zmianami organizacyjnymi w obszarze nauki. Oznacza to, że nauka posiadająca własne teoretyczne struktury oraz metody badawcze nie mieści się już w ramach jednej dyscypliny. Należy jednak odróżnić transdyscyplinarność od interdyscyplinarnosci. Trudno jest wprawdzie ustalić jakąś wyraźną i jednoznaczną granicę, ponieważ z jednej strony postulowana jest specjalizacja w oderwaniu od tradycyjnych dyscyplin, a z drugiej strony powstaje typ nauki ukierunkowanej na praktykę, który łączy kilka dyscyplin. Proces specjalizacji znajduje wyraz w tworzeniu nowych sekcji specjalistycznych towarzystw naukowych, w nowych tytułach czasopism i nazwach katedr. Należy mieć świadomość tego, że im większe będzie rozdrobnienie i specjalizacja, tym szybciej ujawni się potrzeba łączenia tych wąskich specjalności. W szczególności dotyczy to badań nad środowiskiem, zmianami klimatycznymi i skutkami nowych technologii, które ujawnią się za kilkadziesiąt lat. Są to tzw. integrated assessment studies, w których łączy się badania uczonych z zakresu fizyki, chemii, meteorologii, socjologii, psychologii, ekonomii. O tym, czy wyniki badań zostaną zaprezentowane jako interdyscyplinarne decydują ambicje uczonych prowadzących te badania.

Transdyscyplinarności wymagają badania nad ryzykiem występującym w środowisku naturalnym np. dotyczącym zmian klimatu czy przy ocenie możliwych konsekwencji stosowania nowych technologii. W przypadku badań prowadzonych nad zmianami w środowisku i klimacie stwierdza się, że ten ważny obszar badań jest wypadkową działań polityków i uczonych. Rządy, stowarzyszenia ekologów i organizacje, jak np. UNESCO utworzyły międzynarodowe programy badawcze: Intergovernmental Panel on Climate Change (IPCC), w ramach którego regularnie dokonuje się uzgodnień i wytycza kierunki badań, World Climate Research Programme (WCRP), International Council of Scientific Unions (ICSU), World Meteorological Organization (WMO) oraz Intergovernmental Oceanographic Commission (IOC), International Geosphere-Biosphere Programme (IGBP) oraz Human Dimensions of Global Environmental Change Programme (HDP). $\mathrm{W}$ ramach tych licznych programów dokonuje się ujednolicania danych, standaryzacji pomiarów, metodologii, które umożliwiają ponadnarodową komunikację i przekazywanie politykom uzyskanych informacji. Finansowanie ma charakter międzynarodowy i budżety obejmują ogromne kwoty. Poszczególne programy są inicjowane przez uczonych oraz instytucje ponadnarodowe. Uczeni i politycy ustalają cele i priorytety badawcze, a także dzielą środki na cele badawcze i doradcze. Badania są prowadzone przez długi okres czasu, jednak nie stanowią pilnego priorytetu dla polityków stąd ma miejsce powolny postęp w ochronie środowiska naturalnego. Jednocześnie uczony powinien mieć na uwadze możliwość implementacji osiąganych wyników, co dotyka preferencji grup pozostających 
poza systemem nauki i technologii. Otwarta pozostaje kwestia uznania i zaakceptowania wyników badań przez inżynierów, prawników i ludzi biznesu. Chodzi bowiem o prawny aspekt konsekwencji prowadzonych badań i eksperymentów, na przykład klonowania. Wszystko to dzieje się w warunkach niepewności i ryzyka. W związku z tym wśród uczonych pojawia się dążenie do prowadzenia badań w ramach normal science w małych zespołach badawczych. Mają to być zespoły hybrydowe, funkcjonujące w obszarze pomiędzy nauką, polityką i mediami.

Inne nie mniej ,trudne" dziedziny to $\mathrm{m}$. in. biotechnologia, zdrowie, gdzie istnieje otwarta kwestia subiektywnej i społecznej oceny ryzyka. W jakim zakresie podlega ono kryteriom ekonomicznym, politycznym i społecznym? O ile na uczonych spoczywa społeczna odpowiedzialność za prowadzone badania to korzyści często przypadają zakładom produkcyjnym, a przede wszystkim koncernom międzynarodowym. Przemysł czeka na efekty badań, które pozwalają maksymalizować zyski, a niekoniecznie minimalizują ryzyko różnego pochodzenia.

We współczesnym świecie można obserwować procesy unaukowienia polityki, upolitycznienia nauki i upublicznienia nauki poprzez media. Unaukowienie polityki dotyczy zainteresowania polityków problematyką środowiska, zdrowia, energii i technologii, chociaż ich wiedza jest płytka i powierzchowna w tych dziedzinach. Jest to obszar medialny, ponieważ krzyżują się tu elementy nauki i polityki, a poza tym interesują się tym przeciętni obywatele. Można więc na tym zbić kapitał polityczny, zwłaszcza w kampaniach wyborczych. Upolitycznienie nauki ma miejsce w płaszczyznach, w których chodzi o uniwersalne wartości, jak godność człowieka, jego zdrowie, bezpieczeństwo i wolność osobistą oraz rolę państwa w zapewnieniu ich. Prawo narzuca obowiązek uwzględniania najnowszego stanu wiedzy. Zagwarantowanie rozwoju nauki i ocena jej zgodności z prawem, nadaje jej specyficzne cechy polityczne, kiedy np. wskazanie na czynnik ludzki w zakresie zmian klimatycznych skłania polityków do działania. Rządy i organizacje polityczne wykorzystują naukę do legitymizacji własnych interesów. Dlatego też w walce o argumenty konkurują w ośrodkach naukowych o pierwszeństwo w otrzymaniu najnowszych wyników badań. Naukowe rozbieżności i sprzeczne stanowiska uczonych są wykorzystywane przez polityków dla ich własnych celów, np. w dyskusjach nad energią atomową, szkodliwością promieniowania, skutkami AIDS, BSE, genami itp. Wiąże się to również ze wspomnianym unaukowieniem polityki, co ma ułatwiać rządom podejmowanie trudnych decyzji. Instytucjonalna wiedza wskutek upolitycznienia traci swój obiektywizm, ale nie oznacza to, że nauka nie dąży do prawdy.

Wzrost znaczenia mediów w kształtowaniu świadomości publicznej prowadzi w coraz większym zakresie do upublicznienia nauki w mediach. Wiadomości podawane w środkach masowego przekazu legitymizują politykę i polityków. To samo odnosi się do relacji: nauka - media. Rosnąca zależność nauki od mediów przejawia się w różny sposób, a m.in. w staraniach o profesjonalizację dziennikarstwa naukowego poprzez tworzenie stanowisk rzeczników prasowych w instytutach naukowych. Inną formą są dyskusje prowadzone w mediach o zagrożeniach 
i zdywersyfikowanym ryzyku oraz kierowanie uwagi na potrzebę lub konieczność podejmowania odpowiednich działań ze strony polityków. Media eksponują ten aspekt, mówią o coraz większej liczbie zagrożeń, ich zasięgu i coraz horyzoncie czasowym możliwych negatywnych następstw. Obiektywnie twierdząc bez mediów opinia publiczna nie dowiedziałaby się o rezultatach wielu badań naukowych i efektach wielu decyzji politycznych, które mogą nastąpić w przyszłości.

\title{
ZAKOŃCZENIE
}

Koncepcja społeczeństwa informacyjnego określanego też społeczeństwem wiedzy wskazuje na znaczenie nauki, dostępu do informacji i nowych technologii w podnoszeniu świadomego życia człowieka. Koncepcja społeczeństwa ryzyka uwydatnia wzrost niepewności i zagrożeń będących następstwem $\mathrm{m}$. in. postępu technologicznego. Wieloletnie badania nad ryzykiem i doskonalenie metod jego pomiaru nie zlikwidowały dylematów związanych z tym zjawiskiem i jego definiowaniem. Wydaje się, że jedynie transdyscyplinarne i interdyscyplinarne ujęcie ryzyka jest metodą pozwalającą na właściwe uchwycenie jego złożoności, zmienności i dynamiki.

\section{DILEMMAS IN RESEARCH ON RISKS AS A PHENOMENON AND A CATEGORY OF ANALYSIS.}

\begin{abstract}
The study begins with a chronological review of research on risk in various countries and then investigates relationships between the general scientific theory and the use of scientific methodology in this discipline. In this part of the essay, focus is on the essence of experiential learning in relation to diversified risks. The issue is presented primarily to improve risk measurement tools. Another point of the essay is to indicate an interdisciplinary study of diversified risks, including strategies to limit global risks, and emerging risks to the environment. In this context, the Human Choice and Climate Change Report is presented with new methods for testing risk. Studies under risk and risk management are perceived as transdisciplinary with an assumption that this approach is more complete than an interdisciplinary one. The essay concludes with a discussion of the responsibility of scientists for further research on risk and the consequences of progress in science. It is also an introduction to research on the philosophy of risk.
\end{abstract}

Key words: risk management, interdisciplinary approach, global risk, climate changes, diversified risk, transdisciplinary research. 